\title{
ВПЛИВ ТЕХНОГЕННИХ ЧИННИКІВ НА ЕКОЛОГІЧНИЙ СТАН СІЛЬГОСПУГІДЬ ПРОМИСЛОВОГО РЕГІОНУ
}

\author{
Вінюков О. О., Бондарева О. Б.
}

\section{ВСТУП}

Однією з глобальних агроекологічних проблем натепер є забезпечення населення якісними, екологічно безпечними продуктами харчування. Зарубіжний продовольчий ринок значною мірою орієнтований на продукцію, яка відповідає таким показникам. Оскільки Україна є членом COT, то й Україні для забезпечення конкурентоспроможності вітчизняних продуктів харчування i продовольчої сировини треба орієнтуватись на ці вимоги. У країнах СС існує велика кількість чинних нормативів і стандартів 3 якості, ефективно діють загальні й правові акти, мета яких - забезпечити якість і безпеку харчових продуктів. При цьому широко впроваджується методологія отримання якісної $\mathrm{i}$ безпечної сільськогосподарської продукції, принципи якої - перехід від контролю кінцевого продукту до прогнозування можливих негативних впливів та уникнення їх на стадії виробництва. Академік НААН O.I. Фурдичко підкреслює, що «виробництво якісної і безпечної сільськогосподарської продукції та сировини неможливе без урахування екологічного стану агросфери i застосування сучасних екологічно безпечних агротехнологій ${ }^{1} »$.

Показники якості й безпеки продукції значною мірою залежать від агроекологічного стану сільгоспугідь, як наслідок, екологічна безпека рослинної продукції значною мірою залежить від нагромадження в компонентах агросфери полютантів промислового походження, серед яких найбільш поширеними $є$ важкі метали (далі - ВМ) $)^{2}$. Вони можуть забруднювати грунти, змінювати його агрохімічні, мікробіологічні, екологічні властивості, мігрувати і забруднювати поверхневі, грунтові води та рослини ${ }^{3}$. Важкі метали можуть затримувати ріст і розвиток рослин, пригнічувати важливі процеси метаболізму, що в подальшому знижує продуктивність і якість сільськогосподарської продукції ${ }^{4}$. Вчені

\footnotetext{
1 Фурдичко O.I., Дем'янюк О.С. Якість і безпека сільскогосподарської продукції в контексті продовольчої безпеки. Агроекологічний журнал. 2014. № 1. С. 7-12.

2 Хала В.Г., Артемьев В.М., Мешков В.И. Оценка системы «почва-растение» по содержанию и транслокации тяжелых металлов. Агрохимический вестник. 2002. № 4. С. 7-8.

3 Екологічна експертиза технологій вирощування сільськогосподарських культур: метод. рекомендації / За ред. Н.А. Макаренко, В.В. Макаренка. К., 2008. 84 с.

4 Кривіч Н.Я., Білявський Ю.А., Мандзик Я.П. Вміст важких металів у грунті під озимою пшеницею та ії продуктивність залежно від систем удобрення та способів основного обробітку. Вісник Дніпропетровського аграрного університету. 2004. № 1. С. 61-68.
} 
дійшли висновку, що оптимальним є підбір культур агрофітоценозів, які характеризувались би високою продуктивністю та вмістом ВМ у межах встановлених значень ГДК

На початок XXI сторіччя забруднення грунту важкими металами залишається актуальною проблемою великої кількості країн світу та їхніх значних територій. В Україні площа забруднених ВМ грунтів становить 0,5 млн га, або 8,0\% від площі ріллі ${ }^{6}$. Нині близько $20 \%$ території України забруднено важкими металами. Найбільш інтенсивне надходження ВМ у грунти виявлено в місцях розташування підприємств чорної і кольорової металургії, а також гірничорудної промисловості ${ }^{7}$. Взаємодія важких металів із компонентами біосфери вивчається понад два десятиріччя, проте масштаби проблеми не зменшуються внаслідок тривалості їхньої дії і здатності до інтенсивного накопичення в агроландшафтах.

Для регіонів 3 високим рівнем техногенного навантаження на агроценози проблема відповідності сільгосппродукції сучасним стандартам якості й безпеки надзвичайно актуальна. Вирішення іiі потребує дослідження механізму формування такої продукції в умовах індустріальних регіонів, визначення ступеню ризиків, що виникли внаслідок забруднення оточуючого природного середовища. Показники якості та безпеки продукції значною мірою залежать від агроекологічного стану сільгоспугідь ${ }^{8}$. Тому доцільно дослідити структурувати чинники, які впливають на цей показник, що дасть змогу оцінити агроекологічну ситуацію щодо вирощування екологічно безпечних врожаїв.

Найбільшим антропотехногенним навантаженням на агросферу, яке перевищує середньоукраїнський показник у 9-10 разів, характеризується Донецька область. Концентрація промисловості і сільгоспвиробництва, висока щільність населення, розгалужена транспортна мережа зумовлюють руйнацію агробіоценозів, змінення гідрологічного i біогеохімічного режимів, а також мікроклімату в регіоні 9 .

Врахування техногенного впливу на агроландшафти, системне визначення інтенсивності потоків ксенобіотиків 3 промислових агломерацій, особливостей транслокації екотоксикантів у системі

\footnotetext{
5 Самохвалова В.Л., Фатеев А.И., Журавлева И.М. Аспекты изучения и оценка состояния загрязненной тяжелыми металлами системы почва-растение. Агроекологічний журнал. 2008. № 4. С. $38-44$.

${ }^{6}$ Медведев В.В. Мониторинг почв Украины. Концепция. Итоги. Задачи. К.: Городская типография, 2012. $537 \mathrm{c}$.

7 Балюк С.А., Медведєв В.В, Мірошниченко М.М. та ін. Екологічний стан грунтів України. Украӥнський географічний журнал. 2012. № 2. С. 38-42.

8 Бородай Ю.К., Бондарева О.Б., Коноваленко Л.І., Прокопенко Н.Ю. Вплив розсіювання аеральних емісій на агроекологічний стан сільгоспугідь Донецької області. Промышленная ботаника. 2010. Вып.10. С. 54-59.

9 Земля тривоги нашої / За ред. С.В. Третьякова. Донецьк: «ЦЕПИ ЭПИЦентр ЛТД», 2007. 152 с. 
атмосфера - грунт - рослина передбачає використання комплексу чинників, що характеризують агроекологічний стан сільгоспугідь.

\section{1. Закономірності формування зон забруднення важкими металами навкруги техногенних об'сктів та взаємозв'язок рухомості важких металів у грунтах із грунтово-кліматичними умовами й антропогенними чинниками}

За відносно постійних агрохімічних $\mathrm{i}$ агрофізичних показників грунтів, а також геохімічних властивостей підстилаючих порід $\mathrm{i}$ практично збіжних за метеоумовами можливостей промивки грунтів вміст ВМ буде залежати від середньозваженої долі техногенного навантаження. Експериментальними дослідженнями встановлено, що ступінь забруднення грунту ВМ залежить від:

- рівня їх надходження в грунт;

- фізико-хімічних властивостей елементів-токсикантів;

- місцевих грунтово-кліматичних умов;

- інтенсивності процесів міграції ВМ у грунті і транслокації в рослини.

Рівень надходження ВМ у грунт залежить від типу промислового підприємства, в зоні дії якого знаходиться агроландшафт, відстані, напрямку переважаючих вітрів. Середньорічна роза вітрів свідчить, що в Донецькій області переважають східні, південно-східні і північно-східні вітри. Внаслідок цього найбільше розсіювання викидів буде по векторах західного і північно-західного напрямку.

У грунті досліджували вміст валових і рухомих форм міді $(\mathrm{Cu})$, цинку $(\mathrm{Zn})$, свинцю $(\mathrm{Pb})$ і кадмію $(\mathrm{Cd})$.

Для дослідження важких металів у грунті відбирались зразки грунту по відповідних шарах згідно 3 ДСТУ 4287:2004. Якість грунту. Відбирання проб, ДСТУ ISO 10381-2:2004. Якість грунту. Ч. 2. Настанови з методів відбирання проб.

Визначення рівнів вмісту хімічних елементів (міді, цинку, свинцю і кадмію) у пробах грунтів різної буферної здатності i рослинах проводився методом атомно-абсорбційної спектрофотометрії.

Для визначення рухомих форм важкі метали екстрагуються з грунту амонійно-ацетатним буферним розчином з $\mathrm{pH} 4,8$ як екстрагенту, згідно з чинними методиками (ДСТУ 4770.1:2007 - ДСТУ 4770.9:2007 Якість грунту. Визначення вмісту рухомих сполук марганцю (цинку, кадмію, заліза, кобальту, міді, нікелю, хрому, свинцю) у грунті в буферній амонійно-ацетатній витяжці 3 pH 4,8 методом атомно-абсорбційної спектрофотометрі, ДСТУ4770 3:2007. Якість грунту. Визначення вмісту рухомих сполук кадмію в буферній амонійно-ацетатній витяжці з $\mathrm{pH} 4,8$ методом атомно-абсорбційної спектрофотометрії [Чинний від 2009-01-01]. 
К.: Держспоживстандарт України, 2009. 14 с. Національний стандарт України). Для визначення валової кількості важких металів грунт розкладється із застосуванням суміші кислот $\mathrm{HCl}+\mathrm{HNO}_{3}+\mathrm{HF} \quad 3$ подальшим розчиненням залишку в розчині азотної кислоти.

Потенційно рухомі форми важких металів визначались після екстрагування 1 моль/дм ${ }^{3}$ розчином азотної кислоти. Вміст важких металів у рослинних зразках визначався атомно-абсорбційним методом за відомими методиками (Методи аналізів грунтів і рослин. Методичний посібник / за ред. С.Ю. Булигіна та ін. Х.,1999. 157 с.).

Відбір рослинних зразків для проведення агрохімічних аналізів проводився згідно 3 «Методичними вказівками по проведенню досліджень у довготривалих дослідах з добривами». М., 1980.

Важкі метали в рослинних зразках визначали в їх зольних розчинах після спалювання методом сухої мінералізації.

Вміст важких металів у зразках, що досліджувались, визначали атомно-абсорбційним методом на КАС-120.1 у режимі електротермічної атомізації відповідно до «Методических указаний по определению тяжелых металлов в почвах сельхозугодий и продукции растениеводства» ЦИНАО-М., 1992., Обухов А.И., Плеханова И.О. «Атомно-абсорбционный анализ в почвенно-биологических исследованиях» М., Изд-во МГУ, 1991, 184 с.

Математична обробка результатів досліджень виконувалась відповідно до «Методики полевого опыта» Б. А. Доспехова, Москва, 1985.

Експериментальні аналітичні дані вмісту валових форм важких металів у грунтах сільгоспугідь, які знаходяться в зоні дії аерогенних емісій Маріупольської промислової агломерації (чорна металургія, коксохімія), підтверджують, що найбільший вміст полютантів промислового походження в грунті спостерігається по західному i північно-західному напрямкам. Рівень забруднення грунтів важкими металами разом із промисловим пилом зменшується у разі віддалення від джерела викидів, досягаючи фонового вмісту на відстані від 10-15 км до 30-40 км. Значний негативний вплив на земельні ресурси регіону спричиняє накопичення промислових і побутових відходів. У Донецькій області розташовано $31 \%$ і щорічно утворюється $28 \%$ промислових і токсичних відходів держави. Безпосередню небезпеку мають відходи I-III класів небезпеки. Таких відходів, за даними Держуправління охорони оточуючого природного середовища, в Донецькій області накопичено на кінець 2013 p. 6894,2 тис. т. Основними виробниками промислових відходів в області є вугільна, гірничодобувна i металургійна промисловості, а також енергетика. Аналіз розташування полігонів промислових відходів показав, що 
відходи вугледобування сконцентровані по умовній лінії, яка проходить через Покровськ, Донецько-Макіївський і Шахтарський промислові райони. Металургійні відходи розташовані головним чином у містах, де працюють металургійні заводи (Маріуполь, Донецьк, Снакієве). Золошлаки розташовані поблизу теплових електростанцій. Загалом під відходами в області зайнято близько $2 \%$ iї території.

Інфільтрація з полігонів промислових відходів, вітрова і водна ерозія, утворення пилу, аерогенні емісії призводять до забруднення земельних ресурсів, яке підсумовується із забрудненням від аерогенних викидів промислових підприємств.

Базовим показником, який характеризує вплив полігонів промислових відходів на сільгоспугіддя, є відстань до них. Результати експериментальних досліджень свідчать, що надлишок кислих компонентів у складі аерогенних емісій з вугільно-породних відвалів зумовлює різний рівень підкислення грунтів у залежності від їх типів на відстані до 15-20 км (табл. 1).

Таблиця 1

Кислотність грунтів у зоні впливу породних відвалів

\begin{tabular}{|l|c|c|c|c|}
\hline \multirow{2}{*}{ Тип чорноземів } & $\begin{array}{c}\text { Вміст гумусу, * } \\
\%\end{array}$ & \multirow{2}{*}{$\mathrm{pH}^{*}$ грунту } & \multicolumn{2}{|c|}{ Обсяг валових } \\
\cline { 4 - 5 } & емісій, тис. т/рік & $\mathrm{SO}_{2}$ & $\mathrm{NO}_{\mathrm{x}}$ \\
\hline Щебневаті & $4,2(2,9-5,6)$ & $5,7(5,1-6,6)$ & 3,8 & 0,4 \\
\hline $\begin{array}{l}\text { Звичайні } \\
\text { середньогумусні }\end{array}$ & $5,4(5,0-7,6)$ & $6,7(6,2-6,9)$ & 7,7 & 0,9 \\
\hline $\begin{array}{l}\text { Типові } \\
\text { середньогумусні }\end{array}$ & $6,1(5,2-7,5)$ & $6,5(6,0-6,9)$ & 0,9 & 0,1 \\
\hline
\end{tabular}

* у дужках наведено інтервал значень, перед дужками - середнє значення

Хімічний аналіз зразків грунту, що знаходиться під дією емісій 3 породних відвалів, показав, що валовий вміст ртуті і свинцю перевищував фон в усіх зразках i був у межах 0,04-0,18 мг/кг i 15,0-29,1 мг/кг відповідно, цинку - у 90\% зразків, міді - у 34\% зразків, кадмію - у 49\% зразків. Коливання вмісту було таким: цинку 50-75 мг/кг, міді - 18,2-29,6 мг/кг, кадмію - 0,81-1,70 мг/кг.

Відповідно до розташування основних промислових підприємств Донецької області для дослідження нагромадження ВМ у грунті були вибрані сільгоспугіддя, які знаходяться під впливом викидів промисловості різних типів: металургії, коксохімії, енергетики, хімії, вугледобування.

Перевищення ГДК цинку на $10-15 \%$ визначено на сільгоспугіддях, що знаходяться під впливом викидів хімічної, коксохімічної 
промисловості (м. Горлівка ТОВ «Агролен»). У зоні впливу Маріупольського промислового комплексу рівні забрудненості грунтів свинцем як ріллі, так і перелогів були стабільно високими i перевищували фон на 40-50\% та 60-65\% відповідно. Вміст кадмію на перелогах та ріллі перевищував фон на $60-62 \%$ та $15-20 \%$ відповідно. Спостерігається тенденція до збільшення накопичення валових форм кадмію як на перелогах, так і на ріллі.

Вирішальну роль у формуванні екологічно безпечної рослинної продукції відіграє кількість у грунті доступних для рослин форм важких металів. Експериментальні результати свідчать, що для однакових типів грунтів на співвідношення кількості валових і рухомих форм ВМ у грунті впливає склад аерогенних емісій промисловості, тобто її тип (табл. 2).

Таблиця 2

Залежність кількості валових і рухомих форм важких металів у грунтах від типу промисловості (відстань 2 км у напрямку пануючих вітрів)

\begin{tabular}{|l|c|c|c|c|c|c|c|c|}
\hline \multirow{2}{*}{$\begin{array}{c}\text { Тип } \\
\text { промисловості }\end{array}$} & \multicolumn{7}{|c|}{ Масова концентрація, мг/кг } \\
\cline { 2 - 10 } & \multicolumn{2}{|c|}{$\mathrm{Cu}$} & \multicolumn{2}{c|}{$\mathrm{Pb}$} & \multicolumn{2}{c|}{$\mathrm{Zn}$} & \multicolumn{2}{c|}{$\mathrm{Cd}$} \\
\cline { 2 - 10 } & $1^{*}$ & $2 *$ & 1 & 2 & 1 & 2 & 1 & 2 \\
\hline \multirow{2}{*}{ Енергетика } & $22,0-$ & $4,80-$ & $18,9-$ & $1,74-$ & $54,1-$ & $1,40-$ & $0,84-$ & $0,24-$ \\
& 29,1 & 6,50 & 22,8 & 1.89 & 58,0 & 1.80 & 0,96 & 0,36 \\
\hline \multirow{2}{*}{ Металургія } & $26,2-$ & $5,00-$ & $27,3-$ & $1,55-$ & $57,4-$ & $1,77-$ & $0,86-$ & $0,21-$ \\
& 30,2 & 6,10 & 36,4 & 1,40 & 73,6 & 1,91 & 1,02 & 0,31 \\
\hline \multirow{2}{*}{ Вугледобування } & $17,6-$ & $2,90-$ & $14,3-$ & $0,75-$ & $62,5-$ & $0,55-$ & $0,53-$ & $0,07-$ \\
& 21,7 & 3,40 & 22,2 & 1,10 & 70,1 & 0,70 & 0,73 & 0,15 \\
\hline
\end{tabular}

1 *- валові форми, $2 *$ - кислоторозчинні форми

Кислотоутворюючі компоненти аерогенних емісій $\left(\mathrm{SO}_{2}, \mathrm{NO}_{\mathrm{x}}\right)$ збільшують активну рухомість і реакційну здатність важких металів. Це призводить до більшого вмісту рухомих форм ВМ у грунтах сільгоспугідь, які знаходяться в зоні дії викидів металургії та енергетики в порівнянні з вугледобуванням. Так, вміст рухомих форм міді й кадмію в зоні дії викидів металургії і енергетики становить 19,2-22,3\% і $24,4-28,6 \%$ від валового вмісту, а в зоні дії викидів вугледобування $15,7-16,4 \%$ і $13,2-20,5 \%$. На основі розрахунку процентного відношення кількості рухомих форм до валової кількості елементи за збільшенням рухомості розташовуються в ряд $\mathrm{Zn}<\mathrm{Pb}<\mathrm{Cu}<\mathrm{Cd}$.

Інтенсивність накопичення ВМ у грунті залежить як від типу промисловості, так і від відстані до джерела викидів. 3 віддаленням від 
джерела забруднення спостерігається зменшення вмісту валових форм $\mathrm{Cd}, \mathrm{Pb}, \mathrm{Zn}, \mathrm{Cu}$ для металургії і свинцю та цинку для енергетики (табл. 3).

Таблиця 3

Вміст валових і рухомих форм важких металів у грунтах залежно від напряму і відстані від промислових об'сктів

\begin{tabular}{|c|c|c|c|c|c|}
\hline \multirow{2}{*}{ Азимут } & \multirow{2}{*}{$\begin{array}{c}\text { Відстань, } \\
\text { км }\end{array}$} & \multicolumn{4}{|c|}{ Вміст ВМ у грунтах мг/кг } \\
\hline & & $\mathrm{Cd}$ & $\mathrm{Pb}$ & $\mathrm{Zn}$ & $\mathrm{Cu}$ \\
\hline 2 & 3 & 4 & 5 & 6 & 7 \\
\hline \multicolumn{6}{|c|}{ Вплив металургії ( Маріуполь) } \\
\hline $\begin{array}{l}\text { Володарський p-н } \\
\text { північний захід } \\
\text { північний захід } \\
\text { північний захід }\end{array}$ & $\begin{array}{l}10 \\
20 \\
30\end{array}$ & $\begin{array}{c}0,9 / 0,15 \\
0,55 / 0,09 \\
0,50 / 0,07\end{array}$ & $\begin{array}{c}21 / 1,1 \\
15 / 0,8 \\
8 / 0,8\end{array}$ & $\begin{array}{l}70 / 6,0 \\
61 / 5,8 \\
55 / 5,2\end{array}$ & $\begin{array}{l}20 / 3,0 \\
18 / 1,5 \\
18 / 1,5\end{array}$ \\
\hline $\begin{array}{l}\text { Новоазовський р-н } \\
\text { південний схід } \\
\text { південний схід }\end{array}$ & $\begin{array}{l}10 \\
20\end{array}$ & $\begin{array}{l}0,61 / 0,09 \\
0,43 / 0,06\end{array}$ & $\begin{array}{c}16 / 0,8 \\
14,5 / 0,7\end{array}$ & $\begin{array}{l}51 / 5,6 \\
38 / 4,0\end{array}$ & $\begin{array}{l}16,8 / 1,5 \\
14,2 / 1,2\end{array}$ \\
\hline $\begin{array}{l}\text { Тельманівський р-н } \\
\text { південний схід }\end{array}$ & 30 & $0,32 / 0,06$ & $15 / 0,7$ & $30 / 2,7$ & $13 / 1,2$ \\
\hline \multicolumn{6}{|c|}{ Вплив Старобешівської ТЕС } \\
\hline $\begin{array}{l}\text { Старобешівський р-н } \\
\text { Захід, північ. захід } \\
\text { Захід, північ. захід } \\
\text { Захід, північ. захід } \\
\text { Південний, схід } \\
\text { Південний, схід }\end{array}$ & $\begin{array}{l}10 \\
20 \\
30 \\
10 \\
20\end{array}$ & $\begin{array}{l}0,9 / 0,12 \\
0,7 / 0,09 \\
0,8 / 0,10 \\
0,3 / 0,06 \\
0,3 / 0,06 \\
\end{array}$ & $\begin{array}{c}18 / 0,9 \\
16 / 0,8 \\
13,9 / 0,7 \\
16 / 0,8 \\
16 / 0,8 \\
\end{array}$ & $\begin{array}{l}64 / 6,1 \\
58 / 5,6 \\
55 / 5,6 \\
47 / 4,8 \\
44 / 4,6 \\
\end{array}$ & $\begin{array}{c}16 / 1,9 \\
16 / 1,8 \\
17 / 1,9 \\
16 / 1,8 \\
13,5 / 1,7 \\
\end{array}$ \\
\hline $\begin{array}{l}\text { Фоновий (загальний) } \\
\text { вміст }^{10}\end{array}$ & & $<0,3(1,0)$ & $5,0(13,0)$ & $10,0(55,0)$ & $5,0(22,0)$ \\
\hline
\end{tabular}

Примітки: у чисельнику наведено концентрацію валових форм ТМ; у знаменнику наведено концентрацію рухомих форм ТМ (екстракція амонійно-ацетатним буферним розчином $3 \mathrm{pH} \mathrm{4,8)}$

У зоні до 10 км від промплощ відмічено залежність вмісту валових і рухомих форм ВМ від типу виробництва. Так, аерогенні емісії металургійних виробництв, що містять значні кількості ВМ, призводять до підвищеного у порівнянні з викидами енергетики вмісту в грунтах цієї зони Си, $\mathrm{Pb}, \mathrm{Zn}$. На відстанях більш ніж 10 км від джерел промислових викидів концентрація ВМ у грунтах практично не залежить від типу виробництва.

Аналіз літературних джерел і власні дослідження свідчать, що тип грунту, його хімічні властивості суттєво впливають на вміст рухомих форм важких металів і їх транслокацію в рослини. Аналіз фонового вмісту важких металів у різних типах грунтів виявив суттєві відмінності: вміст

\footnotetext{
${ }^{10}$ Самохвалова В.Л., Фатєєв А.І., Лучникова Є.І. Еколого-геохімічна оцінка фонового рівня вмісту різних форм мікроелементів грунту. Вісн. Львівського університету. Серія біологічна. 2011. Вип 55. C. $125-133$.
} 
свинцю був найбільшим у сірих лісових грунтах, вміст цинку, кобальту i міді виявився вищим у більш родючих грунтах, чорнозем вилужений, i темно-сірі лісові грунти відрізнялися великим вмістом хрому ${ }^{11}$. Грунти Донецької області представлені переважно чорноземами типовими звичайними середньогумусними, звичайними малогумусними на лесових породах. Чорноземи, як відомо, характеризуються значною буферністю до важких металів. Водночас для чорноземів у зв'язку з високою ємністю грунтово-геохімічних бар'єрів зростає небезпека прогресивного накопичення важких металів у гумусовому шарі ${ }^{12}$. Верхні гумусові горизонти міцно фіксують важкі метали. Небезпека полягає в тому, що хімічне забруднення довгий час може не виявлятися внаслідок буферності грунту й одночасно бути потужним фактором руйнування біосфери в цілому. Концентрація в грунті рухомих форм тісно пов'язана з хімічним складом техногенних викидів і буферними властивостями грунту ${ }^{13}$.

Експериментально визначено вміст рухомих форм важких металів у грунтах Донецької області різних типів за різним рівнем техногенного навантаження (табл. 4).

Таблиця 4

Вміст важких металів у грунтах різних типів

\begin{tabular}{|c|c|c|c|c|c|c|}
\hline \multirow[b]{2}{*}{ Тип грунту } & \multicolumn{3}{|c|}{ Агрохімічні показники грунту } & \multicolumn{3}{|c|}{$\begin{array}{l}\text { Вміст рухомих форм } \\
\text { важких металів, мг/кг }\end{array}$} \\
\hline & $\begin{array}{c}\text { вміст } \\
\text { гумусу, } \\
\text { \% }\end{array}$ & $\begin{array}{c}\text { вміст } \\
\text { рухомого } \\
\text { фосфору, } \\
\text { мг/кГ }\end{array}$ & рН водн. & $\mathrm{Zn}$ & $\mathrm{Pb}$ & $\mathrm{Cd}$ \\
\hline $\begin{array}{l}\text { Чорноземи звичайні } \\
\text { середньогумусні: }\end{array}$ & & & & & & \\
\hline $\begin{array}{l}\text {-у зоні значного } \\
\text { техногенного } \\
\text { навантаження }\end{array}$ & $\begin{array}{l}3,54 \\
3,73 \\
4,47\end{array}$ & $\begin{array}{c}27 \\
91 \\
115\end{array}$ & $\begin{array}{l}8,3 \\
7,9 \\
8,1\end{array}$ & $\begin{array}{l}1,89 \\
0,77 \\
0,47\end{array}$ & $\begin{array}{l}1,55 \\
1,50 \\
1,48\end{array}$ & $\begin{array}{l}0,25 \\
0,15 \\
0,12\end{array}$ \\
\hline $\begin{array}{l}\text { - в екологічно чистій } \\
\text { зоні }\end{array}$ & $\begin{array}{l}3,00 \\
3,20 \\
3,78\end{array}$ & $\begin{array}{c}130 \\
63 \\
77\end{array}$ & $\begin{array}{l}8,0 \\
8,4 \\
7,8\end{array}$ & $\begin{array}{l}0,96 \\
0,90 \\
0,57\end{array}$ & $\begin{array}{l}0,40 \\
0,20 \\
0,20\end{array}$ & $\begin{array}{l}0,07 \\
0,07 \\
0,05\end{array}$ \\
\hline Чорноземи щебневаті & $\begin{array}{l}2,67 \\
3,14 \\
3,51\end{array}$ & $\begin{array}{c}76 \\
100 \\
96\end{array}$ & $\begin{array}{l}7,0 \\
6,9 \\
7,4\end{array}$ & $\begin{array}{l}0,82 \\
0,61 \\
0,51\end{array}$ & $\begin{array}{l}1,07 \\
1,35 \\
1,43\end{array}$ & $\begin{array}{l}0,15 \\
0,13 \\
0,09\end{array}$ \\
\hline $\begin{array}{l}\text { Чорноземно-лугові } \\
\text { солонцеваті грунти }\end{array}$ & $\begin{array}{l}3,52 \\
4,09 \\
4,65\end{array}$ & $\begin{array}{c}110 \\
80 \\
107\end{array}$ & $\begin{array}{l}8,6 \\
8,5 \\
8,7\end{array}$ & $\begin{array}{l}1,65 \\
0,95 \\
0,83\end{array}$ & $\begin{array}{l}1,10 \\
1,30 \\
1,50\end{array}$ & $\begin{array}{l}0,18 \\
0,20 \\
0,20\end{array}$ \\
\hline
\end{tabular}

\footnotetext{
11 Суюндуков Я.Т., Шагиева Ю.А. Особенности загрязнения черноземов тяжелыми металлами. Аграрная наука. 2008. № 1. С. 10-14.

${ }_{12}$ Медведев В.В., Бука А.Я., Губарева Д.Н. и др. Почвенно-экологические условия возделывания сельскохозяйственных культур / Под ред. В.В. Медведева. Киев: Урожай, 1991. С. 49-58.

13 Фатєєв А.І., Мірошниченко М.М., Бородіна Я.В. та ін. Нормування вмісту міцнофіксованих форм важких металів у грунтах. Вісник аграрної науки. 2011. № 9. С. 41-44.
} 
Для досліджених типів грунтів уміст гумусу i рухомого фосфору впливає на рухомість цинку. Збільшення вмісту гумусу i фосфору зумовлює зменшення вмісту рухомих форм цинку за рахунок утворення малорозчинних або комплексних сполук. Для свинцю і кадмію така залежність $є$ значно меншою. Ці результати збігаються з даними других авторів, згідно з якими стійкість грунтів зони Степу України щодо окремих металів підпорядкована такій послідовності: $\mathrm{Zn}>\mathrm{Ni}>\mathrm{Pb}>$ $\mathrm{Cu}>\mathrm{Co}>\mathrm{Cd}^{14}$.

Фізико-хімічні властивості важких металів впливають на міграцію їх рухомих форм за профілем грунту (табл. 5).

Таблиця 5

Розподіл рухомих форм важких металів по шарах грунту

\begin{tabular}{|c|c|c|c|c|}
\hline \multirow{2}{*}{$\begin{array}{c}\text { Шар } \\
\text { грунту, см }\end{array}$} & \multicolumn{4}{|c|}{ Вміст рухомих форм ВМ, мг/кг } \\
\cline { 2 - 5 } & $\mathrm{Cu}$ & $\mathrm{Zn}$ & $\mathrm{Pb}$ & $\mathrm{Cd}$ \\
\hline $0-20$ & 1,45 & 1,78 & 1,12 & 0,18 \\
\hline $20-40$ & 1,40 & 1,29 & 0,98 & 0,15 \\
\hline $40-60$ & 1,21 & 0,32 & 0,20 & 0,12 \\
\hline
\end{tabular}

Аналіз вмісту важких металів у грунті показав, що рухомі форми свинцю і цинку більшою мірою акумулюються у верхньому гумусному шарі грунту. Іони міді й кадмію характеризуються більшою рухомістю, тому вміст цих компонентів по шарах грунту суттєво не відрізнявся. Така поведінка важких металів, імовірно, пов'язана 3 розчинністю сполук цих елементів, а також зі здатністю утворювати комплексні сполуки.

Суттєвий вплив на вміст елементів-токсикантів у рослинах $\mathrm{i}$ сільськогосподарській продукції має відстань від джерел аерогенних емісій опосередковано через рівні розсіювання пилово-газових емісій у приземному прошарку атмосфери.

У табл. 6 наведені дані по вмісту ВМ у сільгосппродукції, що відбиралась на різних відстанях від промислових агломерацій.

3 наведених даних стає очевидно, що розсіювання пилово-газових емісій над сільгоспугіддями зумовлюють накопичення ВМ у ріллі за ГДК. У чорноземах із високою толерантністю до катіонних токсикантів уміст рухомих і валових форм пов'язаний з нерівноважними процесами в системах: повітря - приземний прошарок атмосфери - поверхневий прошарок грунту (рослини) - орний шар ріллі - рослини.

14 Ильинский А.В. Биологическая очистка почв, загрязненных тяжелыми металлами. Агрохимический вестник. 2003. № 5. С. 30-32. 
Таблиця 6

Вміст важких металів у рослинах у зонах впливу різних рівнів техногенного навантаження

\begin{tabular}{|c|c|c|c|c|c|c|c|c|c|c|c|c|}
\hline \multirow{4}{*}{ Об’єкт аналізу } & \multicolumn{12}{|c|}{ Вміст ВМ, мг/кг } \\
\hline & \multicolumn{3}{|c|}{$\mathrm{Cu}(\Gamma Д К=10)$} & \multicolumn{3}{|c|}{$\mathrm{Pb}(Г Д К=0,5)$} & \multicolumn{3}{|c|}{ 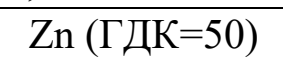 } & \multicolumn{3}{|c|}{$\mathrm{Cd}(\Gamma Д К=0,1)$} \\
\hline & \multicolumn{12}{|c|}{ Відстань до джерел викидів, км } \\
\hline & $\leq 3$ & $5-15$ & $>30$ & $\leq 3$ & $5-15$ & $>30$ & $\leq 3$ & $5-15$ & $>30$ & $\leq 3$ & $5-15$ & $>30$ \\
\hline Різнотрав’я & 7,7 & - & 2,36 & 8,7 & 3,5 & 0,42 & 57,0 & 49,1 & 18,5 & 0,63 & 0,44 & 0,30 \\
\hline $\begin{array}{l}\text { Озима пшениця: } \\
\text { зерно }\end{array}$ & 4,5 & 2,5 & 1,2 & 2,5 & 1,3 & 0,7 & 37,0 & 19,1 & 19,3 & 0,78 & 0,51 & 0,48 \\
\hline солома & 4,9 & 3,7 & 1,9 & 2,8 & 2,3 & 1,0 & 42,2 & 22,5 & 22,2 & 0,96 & 0,58 & 0,52 \\
\hline $\begin{array}{l}\text { Ячмінь ярий: } \\
\text { зерно }\end{array}$ & 10,5 & 6,5 & 6,6 & 1,8 & 1,0 & 0,7 & 26,4 & 14,0 & 14,7 & 1,28 & 0,56 & 0,38 \\
\hline солома & 14,4 & 11,1 & 9,3 & 1,9 & 1,3 & 0,9 & 31,9 & 17,0 & 15,0 & 1,62 & 0,45 & 0,51 \\
\hline
\end{tabular}

\section{2. Комплексна система інтегральних чинників оцінки екологічного стану сільгоспугідь}

Комплексна система критеріальних чинників оцінки екологічного стану сільгоспугідь спрямована на визначення ступеню ризиків, що виникають унаслідок забруднення земель, i дає змогу на стадії планування виробництва враховувати відповідність якості екологічного стану сільгоспугідь (приземного шару атмосфери і грунту до здатності культури формувати на ній екологічно безпечний урожай.

Для оцінки сільгоспугідь щодо вирощування екологічно безпечної продукції одним 3 основних критеріїв $€$ визначення вмісту важких металів у грунті на регіональному рівні, за якого нагромадження цих екотоксикантів у рослинах не перевищує ГДК для продукції. Згідно 3 літературними даними, а також результатами досліджень гранично допустимі концентрації важких металів у грунті не відповідають сучасни екологічним вимогам. Крім того, транслокація цих екотоксикантів у системі грунт-рослина значною мірою залежить від типу культур. Тому виникає необхідність установити допустимі рівні ВМ у грунті для конкретних культур, адже і санітарно-гігієнічне нормування відповідає видам продукції ${ }^{15}$.

У Донецькій області зернові колосові $€$ найбільш поширеними культурами, вони займають $\sim 60 \%$ посівних площ. Були проведені вегетаційні досліди з різними рівнями штучного забруднення грунтів для встановлення допустимих рівнів у для зернових колосових - озимої пшениці та ярого ячменю. Штучне забруднення відповідало рівням забруднення грунтів у регіоні. Вміст потенційно рухомих форм важких металів відповідно до рів забруднення наведено в табл. 7.

\footnotetext{
${ }^{15}$ Шапоренко O.I. Управління станом і використання сільськогосподарських земель у регіоні: монографія. Донецьк: Норд-Прес, 2004. С. 84-85.
} 
Вміст потенційно рухомих форм важких металів у грунті

\begin{tabular}{|l|c|c|c|c|}
\hline \multirow{2}{*}{ Рівень забруднення } & \multicolumn{4}{|c|}{ Вміст важких металів, мг/кг } \\
\cline { 2 - 5 } & $\mathrm{Cu}$ & $\mathrm{Zn}$ & $\mathrm{Pb}$ & $\mathrm{Cd}$ \\
\hline Контроль & 6,4 & 40,5 & 6,8 & 0,12 \\
\hline I рівень & 21,6 & 55,0 & 13,0 & 0,32 \\
\hline II рівень & 37,5 & 110 & 45,3 & 2,1 \\
\hline III рівень & 106,7 & 188 & 72,5 & 6,3 \\
\hline
\end{tabular}

Перевищення ГДК у зерні ярого ячменю та озимої пшениці відмічено по міді і свинцю за третім рівнем забруднення, по цинку і кадмію - за другим рівнем забруднення грунту ВМ. На базі отриманих даних розраховано, що для одержання екологічно безпечної продукції зернових колосових коефіцієнти техногенної концентрації (перевищення фонового вмісту по валових формах) можуть становити: $\mathrm{Cu} \leq 1,5$, $\mathrm{Zn} \leq 1,3, \mathrm{~Pb} \leq 10,0, \mathrm{Cd} \leq 1,5$. Коренева система зернових колосових має певний бар'єр щодо свинцю, цим зумовлений більш високий допустимий коефіцієнт техногенної концентрації. При цьому коефіцієнти біологічного поглинання для озимої пшениці та ярого ячменю відрізнялись несуттєво і становили по свинцю 0,03-0,04, по міді - 0,1-0,2, по цинку - 0,15, по кадмію - 0,02. Ряд інтенсивності поглинання металів пшеницею озимою і ячменем ярим такий: $\mathrm{Zn}>\mathrm{Cu}>$ $\mathrm{Pb}>\mathrm{Cd}$. Досліди показали, що коренеплоди характеризуються більш високим накопиченням важких металів. Так, для буряка столового коефіцієнти біологічного поглинання були такими: по свинцю $-0,16$, по міді $-0,8$, по цинку $-0,7$, по кадмію $-0,4$. Ряд інтенсивності поглинання металів для буряку столового: $\mathrm{Cu}>\mathrm{Zn}>\mathrm{Cd}>\mathrm{Pb}$. Таким чином, різні види рослин мають різну здатність поглинати і накопичувати метали. При цьому прямої залежності між рівнем забруднення грунту i надходженням ВМ у рослини не спостерігалось.

Якісний і кількісний склад аерогенних емісій зумовлює накопичення різноманітних токсичних речовин в агроландшафтах. При цьому відмічається їх розповсюдження на значні відстані від джерел забруднення. Під час розроблення агроекологічного обгрунтування диференціації територій, як показали дані агроекологічного моніторингу, доцільно використовувати такі основні чинники, що враховують особливості стану агрогеобіоценозів у регіоні:

- повітряно-міграційний (А);

- грунтово-адсорбційний $(Г)$;

- водно-акумулятивний (В);

- фітотранслокаційний (Т);

- агрохімічно-поживний (П); 
- інші (Ф).

У загальному вигляді вплив перелічених факторів на агроекологічний стан (Ет) сільськогосподарських угідь можна записати у вигляді рівняння:

$$
E_{T}=\frac{\alpha \cdot A+\beta \cdot B+\gamma \cdot \Gamma+\tau \cdot T+\rho \cdot \Pi+\ldots+k \cdot \Phi}{n+1},
$$

де $\alpha, \beta, \gamma, \tau, \rho, \mathrm{k}$ - емпіричні коефіцієнти для конкретних умов, сільськогосподарських культур і агротехнологій.

Повітряно-міграційний складник змінюється від 0,1 до 1,0 відповідно до ізоліній ГДК і залежить від типу викидів, що розсіюються над сільськогосподарськими угіддями в приземному прошарку. Аналіз методик розрахунку ізоліній ГДК, а також складових рівнянь, що визначають залежності величин впливу компонентів аерогенних емісій на сільськогосподарські угіддя, свідчать про відповідність інтенсивності, висоти джерел викидів і відстані від них, а також рельєфу місцевості та метеоумов $^{16}$. Тому, ймовірно, що для умов розташування основних промислових агломерацій найбільш суттєвою буде відстань земель сільськогосподарського призначення від джерел викидів в атмосферу та їх походження. Форми існування основних токсикантів залежать від багатьох факторів, але переважно від характеру виробництва, відповідності технологій та очисного обладнання екологічним вимогам i нормативам. Для регіону традиційно найбільший внесок у забруднення атмосфери, грунту, вод, рослин вносять енергетика, металургія, вуглевидобувна промисловість, коксохімія тощо (табл. 8).

Таблиця 8

Вплив промислових ксенобіотиків на агроценози

\begin{tabular}{|l|l|l|}
\hline \multicolumn{1}{|c|}{$\begin{array}{c}\text { Тип промисловості, } \\
\text { характер викидів }\end{array}$} & \multicolumn{1}{|c|}{$\begin{array}{c}\text { Хімічний склад } \\
\text { аерогенних емісій }\end{array}$} & \multicolumn{1}{c|}{$\begin{array}{c}\text { Токсична дія } \\
\text { пило-газових сумішей }\end{array}$} \\
\hline $\begin{array}{l}\text { Металургія, організовані й } \\
\text { роздільні [24] }\end{array}$ & $\begin{array}{l}\text { Пил з } \mathrm{BM}, \mathrm{SO}_{2}, \mathrm{NO}_{\mathrm{x}}, \\
\mathrm{CO}, \mathrm{HCN} \text { та ін., } \\
\mathrm{pH} \mathrm{5-7}\end{array}$ & $\begin{array}{l}\text { Ураження листової поверхні, } \\
\text { змінення морфологічних } \\
\text { ознак, зменшення } \\
\text { продуктивності культур і } \\
\text { якості продукції }\end{array}$ \\
\hline $\begin{array}{l}\text { Енергетика, організовані, } \\
\text { сумісні [34] }\end{array}$ & $\begin{array}{l}\text { Пил 3 } \mathrm{BM}, \mathrm{SO}_{2}, \mathrm{NO}_{\mathrm{x}}, \\
\mathrm{CO}, \mathrm{HF}, \mathrm{pH} 2-4\end{array}$ & $\begin{array}{l}\text { Деградація фітоценозів, зміна } \\
\text { фізіологічних ознак і } \\
\text { структура рослинності. } \\
\text { Погіршення якості продукції }\end{array}$ \\
\hline $\begin{array}{l}\text { Вугледобувна } \\
\text { промисловість, переважно } \\
\text { не організовані й роздільні } \\
\text { аеральні емісії [35] }\end{array}$ & $\begin{array}{l}\text { Пил з } \mathrm{BM}, \mathrm{As}, \mathrm{SO}_{2}, \\
\mathrm{Se}, \mathrm{H}_{2} \mathrm{~S}, \mathrm{NH}_{3}, \text { феноли, }_{\mathrm{x}}, \mathrm{HF}, \mathrm{Byглеводні,}_{\mathrm{pH} 2-5}\end{array}$ & $\begin{array}{l}\text { Накопичення токсикантів } \\
\text { органічного походження, } \\
\text { забруднення продукції } \\
\text { ксенобіотиками }\end{array}$ \\
\hline
\end{tabular}

\footnotetext{
16 Чернигова В.А., Чекереса А.И. Агроэкология. Методология, технология, экономика. Москва, «Колос», 2004. 398 с.
} 
Токсиканти з аерогенних емісій підвищують кислотність грунту, вміст ВМ, органічних ксенобіотиків. При цьому зменшується продуктивність культур і харчова цінність продукції.

В узагальненому вигляді 3 урахуванням даних агроекологічного моніторингу, матеріалів ${ }^{17}$ для Донецької області токсична дія викидів на 90\% корелює з відстанню земель сільськогосподарського призначення до джерел розповсюдження аерозолів промислового походження.

Вплив потоків ксенобіотиків 3 водних джерел, на відміну від забруднювачів атмосфери, може бути представлений більш простими залежностями, які пов'язані з вододілами регіону. До цього ж додається інтоксикація води дренажами зі шламонакопичувачів, сміттєзвалищ та полігонів побутових і промислових відходів.

Критеріалізація повітряно-міграційного чинника в межах 0,1-1,0 пов'язана з відстанню сільськогосподарських угідь від джерел викидів, типом промисловості та «розою» вітрів.

Величина критерію водно-акумулятивного впливу на можливість одержання екологічно безпечної сільськогосподарської продукції також може бути в межах 0,1-1,0 у залежності від відстані до промагломерацій, а також поверхневих водних джерел. Для більш посушливих регіонів (Володарський, Великоновоселківський, Волноваський, частини Тельманівського i Амвросієвського) ця величина становить 0,2-0,3. У межах основних промислових агломерацій, відповідно до даних моніторингу, вона сягає 0,8-1,0.

Грунтово-адсорбційний показник залежить від агрохімічних i агрофізичних властивостей грунту $^{18}$ i в значній мірі пов'язаний 3 величинами розсіювання пилу з викидів і аерогенних емісій. Таким чином, величина цього чинника збігається зі значеннями впливу повітряно-міграційного показника.

Транслокація токсикантів у рослини на $60-80 \%$ зумовлена рухомістю i ефективною концентрацією компонентів в аерозолях ${ }^{19}$. Це дозволяє використовувати для оцінки фітотранслокаційного чинника величини, що характеризують вплив промислових агломерацій на сільськогосподарські угіддя.

Для забезпечення можливості оцінювання агроекологічного стану сільгоспугідь щодо вирощування безпечної рослинницької продукції запропоновано відповідну градацію (табл. 9).

17 Справочник по содержанию малых элементов в товарной продукции угледобывающих углеобогатительных предприятий Донецкого бассейна. Днепропетровск, 1994. 187 с.

${ }^{18}$ Перепелиця О.П. Властивості та екологічний вплив хімічних елементів. Київ, 1996. 191 с.

${ }^{19}$ Міністерство палива та енергетики України. ГДК 34. 02. 305 - 2202. Викиди забруднюючих речовин в атмосферу від енергетичних установок. Методика вивчення. Київ, 2002. 115 с. 
Таблиця 9

Характеристика градацій стану сільгоспугідь щодо впливу техногенного навантаження за умовами вирощування екологічно безпечної продукції рослинництва

\begin{tabular}{|c|c|c|}
\hline $\begin{array}{c}\text { Стан } \\
\text { сільгоспугідь }\end{array}$ & $\begin{array}{c}\text { Основні характеристики техногенного } \\
\text { навантаження }\end{array}$ & $\begin{array}{c}\text { Забруднення } \\
\text { рослин }\end{array}$ \\
\hline $\begin{array}{c}0 \text { - екологічно } \\
\text { безпечний }\end{array}$ & $\begin{array}{l}\text { Зони ГДК по сірчанистому ангідриду } \leq 0,05, \text { по } \\
\text { оксидах азоту і пилу } \leq 0,1 \text {. Перевищення фону по } \\
\text { вмісту важких металів у грунті } \leq 1 \text {. } \\
\text { Інтегральний показник AEC }-0,1 \text {. }\end{array}$ & Відсутне \\
\hline 1 - задовільний & $\begin{array}{l}\text { Зони ГДК по сірчанистому ангідриду - } 0,05-0,2, \\
\text { по оксидах азоту і пилу } 0,1-0,5 . \text { Перевищення } \\
\text { фону по вмісту важких металів у грунті: } \\
\mathrm{Cu} \leq 1,5 ; \mathrm{Zn} \leq 1,3 ; \mathrm{Pb} \leq 10,0 ; \mathrm{Cd} \leq 1,5 \text {. } \\
\text { Інтегральний показник AEC }-0,2-0,3 \text {. }\end{array}$ & Відсутнє \\
\hline 2 - допустимий & $\begin{array}{l}\text { Зони ГДК по сірчанистому ангідриду }-0,2-1,0, \\
\text { по оксиду азоту і пилу - } 1-4 \text {. Перевищення } \\
\text { фону по вмісту важких металів у грунті: } \\
\mathrm{Cu}, \mathrm{Zn} \leq 3 ; \mathrm{Pb} \leq 12 ; \mathrm{Cd} \leq 9 \text {. } \\
\text { Iнтегральний показник AEC }-0,3-0,7 \text {. }\end{array}$ & $\begin{array}{l}\text { на рівні ГДК } \\
\text { для продукції }\end{array}$ \\
\hline 3 - критичний & $\begin{array}{l}\text { Зони ГДК по сірчанистому ангідриду -, } \\
\text { по оксиду азоту і пилу - 0,5-1,0. Перевищення } \\
\text { фону по вмісту міді й цинку в грунті > 3, } \\
\text { по кадмію >6, по свинцю > } 12 \text {. } \\
\text { Інтегральний показник АЕС >0,7. }\end{array}$ & $\begin{array}{c}\text { більше від } \\
\text { ГДК } \\
\text { для продукції }\end{array}$ \\
\hline
\end{tabular}

Визначним фактором, який формує агроекологічний стан сільськогосподарських угідь, $є$ інтенсивність техногенного навантаження, що визначається зазначеними чинниками. На основі експериментальних даних і розрахованих сумарних величин - чинників впливу ТЕС на агросферу (табл. 10) - показана можливість оцінки агроекологічного стану сільгоспугідь відповідно до можливості вирощування екологічно безпечної сільськогосподарської продукції ${ }^{20}$.

Таблиця 10

Інтегральні величини чинників техногенного навантаження за напрямом переважаючих вітрів від ТЕС

\begin{tabular}{|c|c|c|c|c|c|c|}
\hline Імовірна & Відстань від & \multicolumn{3}{|c|}{ Значення показників складових } & Інтегральний \\
\cline { 3 - 5 } зона & ТЕС, км & $\mathrm{A}$ & $\Gamma$ & $\mathrm{B}$ & $\mathrm{T}$ & показник \\
\hline ТТ3 & 5 & 1 & 1 & 1 & 1 & 1 \\
\hline ТT3 & 10 & 0,8 & 0,8 & 0,8 & 0,8 & 0,8 \\
\hline P3 & 20 & 0,5 & 0,5 & 0,7 & 0,5 & 0,6 \\
\hline П3 & 30 & 0,1 & 0,1 & 0,2 & 0,1 & 0,1 \\
\hline
\end{tabular}

20 Патика В.П., Тараріко О.Г. Агроекологічний моніторинг та паспортизація сільськогосподарських земель. К.: Фітосоціоцентр, 2002. 296 с. 
Класифікація територій регіону за інтенсивністю техногенного пресингу за даними АЕМ і відповідно до вимог ${ }^{21}$ дозволяє прогностично виділяти три основні зони:

- техногенно-трансформовані ландшафти, де самовідновлення практично не можливе (ТТЗ);

- сільгоспугіддя 3 помірним техногенним навантаженням, буферний потенціал грунтів повністю не вичерпаний (Р3);

- території, перспективні для створення сировинних зон для виробництва екологічно чистої продукції (ПЗ).

Сільгоспугіддя ПЗ характеризуються достатнім потенціалом i високою буферністю агросистеми, що забезпечує самовідновлення. У господарствах, що потрапляють у цю зону, прогнозується виробництво екологічно чистої сільськогосподарської продукції.

Території, перспективні (ПЗ) для цієї мети, мають Ет до 0,3; за наявності екологічних ризиків (Р3) Ет $=0,3-0,7$ техногеннотрансформована зона (ТТЗ) характеризується Ет $>0,7$.

Для розроблення агроекологічного обгрунтування диференціації територій різного призначення визначені допустимі відстані від виробництв різних галузей промисловості (табл. 11). Конкретною i більш переконливою характеристикою агроекологічного стану агроландшафтів для виробництва екологічно безпечної продукції $\epsilon$ концентрації типових для регіону токсикантів: у грунтах; воді різних водних об'єктів; рослинах і сільськогосподарській продукції.

Таблиця 11

Імовірна придатність сільгоспугідь по вимогах розташування від промислових підприємств і агломерацій

\begin{tabular}{|l|c|c|c|}
\hline \multirow{2}{*}{$\begin{array}{c}\text { Галузі } \\
\text { промисловості }\end{array}$} & \multicolumn{3}{|c|}{ Відстань від промислових площ, км } \\
\cline { 2 - 4 } & П3 & Рарактеристика зони & ТТ3 + С33 \\
\hline & \multicolumn{3}{|c|}{ За напрямком переважаючих вітрів } \\
\hline металургія & $\geq 30$ & $12-30$ & $<10$ \\
\hline енергетика (ТЕС) & $\geq 30$ & $15-30$ & $<15$ \\
\hline вуглевидобувна & $\geq 15$ & $5-15$ & $<5$ \\
\hline коксохімія & $\geq 20$ & $5-20$ & $<5$ \\
\hline & \multicolumn{3}{|c|}{ За іншими напрямками вітрів } \\
\hline металургія & $\geq 15$ & $5-15$ & $<5$ \\
\hline енергетика & $\geq 7$ & $4-7$ & $<4$ \\
\hline вуглевидобувна & $>7$ & $3-7$ & $<3$ \\
\hline коксохімія & $>4$ & $2-4$ & $<2$ \\
\hline
\end{tabular}

21 Оцінка придатності сільськогосподарських угідь вимогам спеціальних сировинних зон (методичні рекомендації) / За ред. академіка УААН О.І. Фурдичка. К., 2006. 20 с. 
У залежності від форм існування ксенобіотиків, геохімічних бар'єрів тощо кожен із вищеперелічених показників може бути індикатором інтенсивності негативного впливу промагломерацій на сільськогосподарське виробництво. Проте визначальним для сільськогосподарських угідь з переважно чорноземними грунтами, які мають високу толерантність до іонів ВМ, є концентрація цих речовин у приземному прошарку атмосфери. Отримані експериментальні результати, дані вітчизняних і закордонних авторів підтверджують механізм транслокації ВМ у вегетуючі рослини безпосередньо 3 аерогенних емісій ${ }^{22}$.

У загальному вигляді в першому наближенні концентрація ВМ у рослинах $\left(\mathrm{C}_{\mathrm{p}(3)}\right)$ складається 3 концентраційних залежностей рухомих форм $\mathrm{BM}$ у грунтах $\left(\mathrm{C}_{\mathrm{r}}^{\mathrm{BM}}\right)$ і приземному прошарку атмосфери $\left(\mathrm{C}_{\text {атм }}{ }^{\mathrm{BM}}\right)$ через коефіцієнти транслокації $\left(\mathrm{K}_{\mathrm{T}}\right)$ i ефективного поглинання $\left(\mathrm{K}_{\mathrm{n}}\right)$, відповідно:

$$
\mathrm{C}_{\mathrm{p}(3)}{ }^{\text {вм }}=\mathrm{K}_{\mathrm{T}} \mathrm{C}_{\mathrm{r}}{ }^{\text {вм }}+\mathrm{K}_{\mathrm{n}} \mathrm{C}^{\text {вм }}+\mathrm{C}_{\mathrm{x}}{ }^{\text {вм }}
$$

3 урахуванням транспорту важких металів 3 агрохімікатів $\left(\mathrm{C}_{\mathrm{x}}{ }^{\mathrm{BM}}\right)$. Для чорноземів з високою толерантністю до важких металів i, вочевидь, за межами техногенно-трансформованих зон $\mathrm{C}_{\Gamma}^{\text {вм }} \epsilon$ величиною постійною, a $K_{\mathrm{T}}$ для однакового виду рослин теж постійне $\left(\mathrm{K}_{\mathrm{T}} \mathrm{C}=\beta=\right.$ const). Таким чином, рівняння (1) має вигляд:

$$
\mathrm{C}_{\mathrm{p}(3)}{ }^{\text {вм }}=\beta+\mathrm{K}_{\mathrm{n}} \mathrm{C}^{\text {вм }}+\mathrm{C}_{\mathrm{x}}{ }^{\text {вм }}
$$

За умови, що: $\mathrm{K}_{\mathrm{n}}=\mathrm{K}_{\mathrm{p}}+\mathrm{K}_{\mathrm{f}}$, де $\mathrm{K}_{\mathrm{p}}-$ коефіцієнт рухомості, $\mathrm{K}_{\mathrm{f}}-$ коефіцієнт фітоадсорбції.

Коефіцієнт рухомості $\left(\mathrm{K}_{\mathrm{p}}\right)$ визначається якісним і кількісним складом аерогенних емісій і суттєво залежить від кінетики утворення біодоступних форм ВМ у викидах в атмосферу. Розраховані $K_{\mathrm{p}} 3$ визначенням частини біодоступних форм важких металів становлять для пило-газових аерозолів:

- ТЕС, ТЕЦ та інших енергетичних об'єктів, де спалюють кам'яне вугілля і мають місце організовані сумісні викиди - 0,6-0,8;

- металургії 3 повним циклом 3 організованими і роздільними викидами - 0,10-0,40;

- відвалів териконів, шламонакопичувачів 3 неорганізованими роздільними емісіями - 0,10-0,30.

За умови, що для одного виду рослин величина фітоадсорбції постійна, тобто $\mathrm{K}_{\mathrm{f}}=$ const або за $\beta+\mathrm{K}_{\mathrm{n}} \mathrm{C}^{\text {вм }}=\mathrm{const}=\mathrm{G}$, рівняння (1) приймає вигляд:

$$
\mathrm{C}_{\mathrm{p}(3)}{ }^{\text {вм }}=\mathrm{G}+\mathrm{K}_{\mathrm{p}} \mathrm{C}^{\text {вм }}+\mathrm{C}_{\mathrm{x}}{ }^{\text {вм }}
$$

\footnotetext{
${ }^{22}$ Староверова А.В., Ващенко Л.Б. Нормирование токсикантов в почвах и продуктах питания. Агрохимический вестник. 2000. № 2. С. 7-10.
} 
Транслокація важких металів у рослини одного виду, а також за однакових агротехнологіях буде зумовлюватись для регіонів 3 техногенним навантаженням переважно поглинанням токсикантів 3 приземного прошарку атмосфери:

$$
\mathrm{C}_{\mathrm{p}(3)}{ }^{\text {вм }}=\mathrm{K}_{\mathrm{p}} \mathrm{C}^{\mathrm{o}}+\mathrm{G}
$$

Агроекологічний моніторинг ріллі та аналіз статистичних даних по врожайності зернових колосових дозволили визначити взаємозв'язок між зниженням продуктивності агроценозів і сумарною концентрацією $\mathrm{SO}_{2}$ і пилу (ізолінії ГДК), що розсіюються над вегетуючими рослинами.

На прикладі впливу викидів Маріупольського промвузла, який характеризується розсіюванням $\sim 400$ т/рік аеральних емісій, проведена оцінка негативної дії на врожайність зернових колосових. 3 метою коректної оцінки сукупного впливу $\mathrm{SO}_{2}$ i пилу 3 Маріупольського промвузла на врожайність було зроблено ранжування господарств. Максимальна врожайність господарств у виборці оцінювалась у 8 балів, інші - у 2, 3, 4, 5, 6, 7. Мінімальна, відповідно, в один бал. Імовірність мінімальної врожайності (К) у виборці розраховувалась:

$$
K=\frac{F_{K}-F_{i}}{F_{K}} \cdot 100,
$$

де $\mathrm{F}_{\mathrm{K}}$ - сума балів господарства за максимальної врожайності; $\mathrm{F}_{\mathrm{i}}$ сума балів господарства по матриці.

Вибірка містила дані про врожайність сільськогосподарських культур у п'яти господарствах, розташованих на відстані від 5 км до 30 км від Маріупольського промвузла за 20 років. За математичної обробки цих даних виведене рівняння залежності ймовірної мінімальної врожайності (Q) від відстані до Маріупольського промвузла та зони розсіювання $\mathrm{SO}_{2}$ і пилу:

$$
Q=249,4 \cdot l^{-0.783},
$$

де $l$ - відстань до Маріупольського промвузла, км.

Коефіцієнт кореляції в цьому рівнянні дорівнює 0,9254 .

3 використанням наведеної залежності розрахована ймовірність мінімальної врожайності для південно-східної промислової агломерації. Одержані дані задовільно корелюють із фактичними i можуть використовуватися під час проектування сировинних зон.

\section{ВИСНОВКИ}

Встановлені закономірності формування зон забруднення грунтів важкими металами (BM) під впливом промисловості. Інтенсивність накопичення ВМ у грунті залежить як від типу промисловості, так і від відстані до джерела викидів. 3 віддаленням від джерела забруднення 
спостерігається зменшення вмісту валових форм кадмію $(\mathrm{Cd})$, свинцю $(\mathrm{Pb})$, цинку $(\mathrm{Zn})$, міді $(\mathrm{Cu})$. У зоні до 10 км від промплощ відмічено залежність вмісту валових і рухомих форм ВМ від типу виробництва. На відстанях більш ніж 10 км від джерел промислових викидів концентрація ВМ у грунтах практично не залежить від типу виробництва.

Визначено, що концентрація в грунті рухомих форм ВМ тісно пов'язана 3 хімічним складом техногенних викидів, буферними властивостями грунту і фізико-хімічними властивостями елементів. Рухомі форми свинцю і цинку акумулюються у верхньому гумусному шарі грунту, мідь і кадмій мігрують до більш глибоких шарів грунту.

Виявлено різну інтенсивність біогенної міграції для елементів. По інтенсивності міграції із грунту в рослини пшениці озимої і ячменю ярого елементи розташовуються в ряд $\mathrm{Zn}>\mathrm{Cu}>\mathrm{Pb}>\mathrm{Cd}$.

Визначним фактором, який формує агроекологічний стан сільськогосподарських угідь, $є$ інтенсивність техногенного навантаження.

Розроблено комплексну систему критеріальних чинників оцінки екологічного стану сільгоспугідь, яка спрямована на визначення ступеню ризиків, що виникають унаслідок забруднення земель, і дає змогу на стадії планування виробництва враховувати відповідність якості стану сільгоспугідь (приземного шару атмосфери і грунту) до здатності культури формувати на ній екологічно безпечний урожай.

\section{АНОТАЦІЯ}

Вирішення проблеми отримання екологічно безпечної продукції на територіях, що зазнають значного техногенного тиску, неможливе без урахування міграції і акумуляції важких металів (BM) у грунтовому профілі. Для розуміння процесів міграції та акумуляції важких металів необхідно враховувати джерела їх надходження в агроландшафти. Даними, які характеризують основні техногенні джерела надходження важких металів у грунти, $є$ промислові викиди забруднюючих речовин у атмосферне повітря, скидання зворотних вод у водні об'єкти, поводження 3 відходами, викиди автотранспорту. Інтенсивність накопичення ВМ у грунті залежить як від типу промисловості, так і від відстані до джерела викидів: 3 віддаленням від джерела забруднення спостерігається зменшення вмісту валових форм кадмію $(\mathrm{Cd})$, свинцю $(\mathrm{Pb})$, цинку $(\mathrm{Zn})$, міді $(\mathrm{Cu})$. Концентрація в грунті рухомих форм $\mathrm{BM}$ тісно пов'язана 3 хімічним складом техногенних викидів, буферними властивостями грунту і фізико-хімічними властивостями елементів. Рухомі форми свинцю і цинку акумулюються у верхньому гумусному шарі грунту, форми міді й кадмію мігрують до більш глибоких шарів грунту. За інтенсивністю міграції із грунту в рослини пшениці озимої і ячменю ярого елементи розташовуються в ряд $\mathrm{Zn}>\mathrm{Cu}>\mathrm{Pb}>\mathrm{Cd}$. 
Визначним фактором, який формує агроекологічний стан сільськогосподарських угідь, $€$ інтенсивність техногенного навантаження. Комплексна система критеріальних чинників оцінки стану сільгоспугідь спрямована на визначення ступеню ризиків, що виникають унаслідок забруднення земель, і дає змогу під час планування виробництва враховувати відповідність якості екологічного стану сільгоспугідь формуванню на ній екологічно безпечного врожаю.

\section{ЛІТЕРАТУРА}

1. Фурдичко O.I., Дем'янюк O.C. Якість i безпека сільскогосподарської продукції в контексті продовольчої безпеки. Агроекологічний журнал. 2014. № 1. С. 7-10.

2. Хала В.Г., Артемьев В.М., Мешков В.И. Оценка системы «почварастение» по содержанию и транслокации тяжелых металлов. Агрохимический вестник. 2002. № 4. С. 7-8.

3. Екологічна експертиза технологій вирощування сільськогосподарських культур : метод. рекомендації / за ред. Н.А. Макаренко, В.В. Макаренка. Київ, 2008. 84 с.

4. Кривіч Н.Я., Білявський Ю.А., Мандзик Я.П. Вміст важких металів у грунті під озимою пшеницею та ії продуктивність залежно від систем удобрення та способів основного обробітку. Вісник Дніпропетровського аграрного університету. 2004. № 1. С. 61-68.

5. Самохвалова В.Л., Фатеев А.И., Журавлева И.М. Аспекты изучения и оценка состояния загрязненной тяжелыми металлами системы почварастение. Агроекологічний журнал. 2008. № 4. С. 38-44.

6. Медведев В.В. Мониторинг почв Украины. Концепция. Итоги. Задачи. Киев : Городская типография, 2012. 537 с.

7. Екологічний стан грунтів України / С.А. Балюк та ін. Украӥнський географічний журнал. 2012. № 2. С. 38-42.

8. Вплив розсіювання аеральних емісій на агроекологічний стан сільгоспугідь Донецької області / Ю.К. Бородай та ін. Промышленная ботаника. 2010. Вып. 10. С. 54-59.

9. Земля тривоги нашої / за ред. С.В. Третьякова. Донецьк : «ЦЕПИ ЭПИЦентр ЛТД», 2007. 152 с.

10. Самохвалова В.Л., Фатєєв А.І., Лучникова Є.І. Еколого-геохімічна оцінка фонового рівня вмісту різних форм мікроелементів грунту. Вiсн. Львівського університету. Серія Біологічна. 2011. Вип. 55. С. 125-133.

11. Суюндуков Я.Т., Шагиева Ю.А. Особенности загрязнения черноземов тяжелыми металлами. Аграрная наука. 2008. № 1. С. 10-14.

12. Почвенно-экологические условия возделывания сельскохозяйственных культур / В.В. Медведев и др. ; под ред. В.В. Медведева. Киев : Урожай, 1991. С. 49-58. 
13. Нормування вмісту міцнофіксованих форм важких металів у грунтах / А.І. Фатєєв та ін. Вісник аграрної науки. 2011. № 9. С. 41-44.

14. Ильинский А.В. Биологическая очистка почв, загрязненных тяжелыми металлами. Агрохимический вестник. 2003. № 5. С. 30-32.

15. Шапоренко O.I. Управління станом і використання сільськогосподарських земель у регіоні : монографія. Донецьк : Норд-Прес, 2004. C. $84-85$.

16. Чернигова В.А., Чекереса А.И. Агроэкология. Методология, технология, экономика. Москва : «Колос», 2004. 398 с.

17. Справочник по содержанию малых элементов в товарной продукции угледобывающих углеобогатительных предприятий Донецкого бассейна. Днепропетровск, 1994. 187 с.

18. Перепелиця О.П. Властивості та екологічний вплив хімічних елементів. Київ, 1996. 191 с.

19. Міністерство палива та енергетики України. ГДК 34. 02. 305 2202. Викиди забруднюючих речовин в атмосферу від енергетичних установок. Методика вивчення. Київ, 2002. 115 с.

20. Патика В.П., Тараріко О.Г. Агроекологічний моніторинг та паспортизація сільськогосподарських земель. Київ : Фітосоціоцентр, 2002. $296 \mathrm{c}$.

21. Оцінка придатності сільськогосподарських угідь вимогам спеціальних сировинних зон (методичні рекомендації) / за ред. академіка УААН О.І. Фурдичка. Київ, 2006. 20 с.

22. Староверова А.В., Ващенко Л.Б. Нормирование токсикантов в почвах и продуктах питания. Агрохимический вестник. 2000. № 2. C. $7-10$.

Information about authors: Vinyukov A. A.,

Candidate of Agricultural Sciences, Senior Researcher, Director

Donetsk State Agricultural Science Station of the National Academy of Agrarian Sciences of Ukraine

1, Defenders of Ukraine str., Pokrovsk, Donetsk region, 85307, Ukraine

Bondareva O. B.,

Candidate of Technical Sciences, Senior Researcher,

Scientific Secretary

Donetsk State Agricultural Science Station of the National Academy of Agrarian Sciences of Ukraine 1, Defenders of Ukraine str., Pokrovsk, Donetsk region, 85307, Ukraine 